\title{
The knowledge, practices and the extent of occupational exposures to blood among healthcare workers in Colombo; A cross sectional study
}

\author{
Karawita DA ${ }^{1}$, Gunathilake MPW ${ }^{1}$, Hettiarachchi ${ }^{2}$ Ariyaratne KAM$^{1}$, Ariyaratne L ${ }^{3}$, \\ Abeywardena MLDSS ${ }^{3}$,
}

\section{Introduction}

The estimated number of people living with HIV/ AIDS (PLHIV) in Sri Lanka is about 3000 (1) and as of end 2011, a cumulative total of 1,463 HIV cases has been reported to the National STD/AIDS Control Programme (NSACP), Sri Lanka (2). These figures are comparatively low in a country with 20 million people. The country is currently having low level of HIV prevalence among adult population $(<0.03 \%)$ and even among high risk populations HIV prevalence is estimated to be less than $1 \%$ (3). Therefore, the lack of knowledge, skills, and experience of healthcare workers in handling occupational exposure to potentially infectious body fluids make them to carry stigmatizing attitudes towards PLHIV. Therefore, it is important to comprehend the level of occupational exposures and knowledge on management of blood exposures among healthcare workers in order to reduce possible discrimination of PLHIV at healthcare settings. The objective of this article is to describe the prevailing level of occupational exposures to blood, knowledge and practices on accidental occupational exposure among the healthcare workers.

\section{Methods}

Most of HIV related diseases and issues in the country are managed in the public sector by the Central STD Clinic, Colombo, Base Hospital, Angoda (Infectious Disease Hospital) and some of the major tertiary care hospitals such as National Hospital of Sri Lanka (NHSL), De Soyza Maternity Hospital (DMH), Lady Ridgeway Hospital for Children (LRH), and Castle Street Hospital for Women (CSHW) in Colombo district. Doctors, nursing officers, medical laboratory technologists (MLTs), attendants and labourers have been selected from medical wards, surgical wards, operation theatres, gynaecology and obstetrics wards, labour rooms, outpatient departments, and hospital laboratories in those six selected healthcare institutions for the study. These units have been purposively selected on the basis of experience in managing HIV patients, and high possibility of exposure to body fluids.

Quota sampling was used to recruit 832 healthcare workers from those six selected hospitals. Size of each quota was decided by using the proportions of healthcare workers in each category of staff and proportion of staff in each hospital. Sample sizes are indicated in the Table 1.

The self-administered questionnaire was developed through a process of consultative meetings considering the results of focus group discussions (FGD) conducted with various categories of staff in all 6 healthcare institutions. Questionnaire initially developed in English was later translated into Sinhala and Tamil languages with group consensus in a consultative meeting. The potential participants were given required instructions, time and privacy to respond the questions.

Data were directly entered in to the SPSS v16 for analysis. Cross tabulation of data was done for each variable against the category of staff. Ethical clearance for the study was obtained from the ethics review committee of the Faculty of Medicine, University of Peradeniya, Sri Lanka.

${ }^{I}$ National STD/AIDS Control Programme, Sri Lanka, ${ }^{2}$ International Labour Organization (ILO), Sri Lanka, ${ }^{3}$ National Hospital of Sri Lanka 


\section{Results}

\section{(a). Background characteristics}

Mean age of the sample was 41 years (SD, 10.6). Average age of each category of staff has a slight variation and it changes from 38 years to 41.7 years (Table 1)

All healthcare workers have an average of almost 15 years of working experience in their respective jobs. Attendants had the most experience (22.6 years) while labourers had least experience (11 years).
Doctors and MLTs had almost similar years of experience (13.1 years). Nursing officers' average experience in the field was 15.7 years

Over $60 \%$ of healthcare workers in all categories believe that they have ever provided a care to an HIV positive patient. Nearly one third of healthcare workers did not know that they provided care to an HIV patient while $11 \%$ said never provided care to an HIV patient. Almost half (49.8\%) of the hospital labourers had not given care to an HIV positive patient (table 1)

Table 1: Background characteristics of the sample

\begin{tabular}{|c|c|c|c|c|c|c|c|}
\hline \multirow{2}{*}{\multicolumn{2}{|c|}{ Variable }} & \multicolumn{5}{|c|}{ Staff category } & \multirow[b]{2}{*}{ Total } \\
\hline & & \multirow{2}{*}{$\begin{array}{r}\text { Doctors } \\
130\end{array}$} & \multirow{2}{*}{$\begin{array}{r}\begin{array}{r}\text { Nursing } \\
\text { staff }\end{array} \\
205\end{array}$} & \multicolumn{3}{|c|}{ MLTs ${ }^{1}$ Attendants Labourers } & \\
\hline \multicolumn{2}{|l|}{ Sample size (N) } & & & 92 & 154 & 251 & 832 \\
\hline \multicolumn{2}{|c|}{$\begin{array}{l}\text { Mean age in years } \\
\text { (number responded) }\end{array}$} & $\begin{array}{r}41.7 \\
(130) \\
\end{array}$ & $\begin{array}{r}39.9 \\
(205) \\
\end{array}$ & $\begin{array}{l}38.5 \\
(91) \\
\end{array}$ & $\begin{array}{r}48.5 \\
(147) \\
\end{array}$ & $\begin{array}{r}38.1 \\
(246) \\
\end{array}$ & $\begin{array}{r}41.0 \\
(819) \\
\end{array}$ \\
\hline \multicolumn{2}{|c|}{$\begin{array}{l}\text { Mean years of } \\
\text { experience as a } \\
\text { hcalthcare workcr }\end{array}$} & $\begin{array}{r}13.1 \\
\left(\mathrm{SD}^{2}=9.7\right)\end{array}$ & $\begin{array}{r}15.7 \\
\left.D^{2}=10.9\right)\end{array}$ & $\begin{array}{r}13.1 \\
\left.D^{2}=10.1\right)\end{array}$ & $\begin{array}{r}22.6 \\
\left(\mathrm{SD}^{2}=6.1\right)\end{array}$ & $\begin{array}{r}11.1 \\
\left(\mathrm{SD}^{2}=9.0\right)\end{array}$ & $\begin{array}{r}14.9 \\
\left.D^{2}=10.1\right)\end{array}$ \\
\hline \multirow{4}{*}{$\begin{array}{l}\text { Have you ever } \\
\text { provided care to } \\
\text { an HIV patient }\end{array}$} & Yes & $\begin{array}{r}86 \\
(66.7 \%) \\
\end{array}$ & $\begin{array}{r}139 \\
(67.8 \%) \\
\end{array}$ & $\begin{array}{r}79 \\
(85.9 \%) \\
\end{array}$ & $\begin{array}{r}92 \\
(60.9 \%) \\
\end{array}$ & $\begin{array}{r}106 \\
(43.3 \%) \\
\end{array}$ & $\begin{array}{r}502 \\
(61.1 \%) \\
\end{array}$ \\
\hline & No & $\begin{array}{r}24 \\
(18.6 \%) \\
\end{array}$ & $\begin{array}{r}38 \\
(18.5 \%) \\
\end{array}$ & $\begin{array}{r}3 \\
(3.3 \%) \\
\end{array}$ & $\begin{array}{r}46 \\
(30.5 \%) \\
\end{array}$ & $\begin{array}{r}122 \\
(49.8 \%) \\
\end{array}$ & $\begin{array}{r}233 \\
(28.3 \%) \\
\end{array}$ \\
\hline & $\begin{array}{l}\text { Don't } \\
\text { know }\end{array}$ & $\begin{array}{r}19 \\
14.7 \%\end{array}$ & $\begin{array}{r}28 \\
13.7 \%\end{array}$ & $\begin{array}{r}10 \\
10.9 \%\end{array}$ & $\begin{array}{r}13 \\
8.6 \%\end{array}$ & $\begin{array}{r}17 \\
6.9 \%\end{array}$ & $\begin{array}{r}87 \\
10.6 \%\end{array}$ \\
\hline & Total & $\begin{array}{r}129 \\
(100.0 \%)\end{array}$ & $\begin{array}{r}205 \\
(100.0 \%)\end{array}$ & $\begin{array}{r}92 \\
(100.0 \%)\end{array}$ & $\begin{array}{r}151 \\
(100.0 \%)\end{array}$ & $\begin{array}{r}245 \\
(100.0 \%)\end{array}$ & $\begin{array}{r}822 \\
(100.0 \%)\end{array}$ \\
\hline
\end{tabular}

${ }^{1}$ MLT - Medical Laboratory Technologist, ${ }^{2}$ SD - Standard Deviation

\section{(b). Exposure to blood in healthcare settings}

Approximately about one in every ten of HCWs had needle prick injuries during the previous 12 months. Attendants and labourers had the least number of needles prick injuries whereas doctors and nurses had the highest number injuries and it was $23.1 \%$ and $14.1 \%$ respectively (Table 2 )
Small number of cut injuries was also reported from HCWs during the last 12 months. MLTs had the highest number of cut injuries $(13 \%)$ while $8.5 \%$ of doctors also had cut injuries while providing care to patients. Nurses had relatively lower number of cut injuries (3.4\%) than Doctors (Table 2). In focus group discussions with MLTs, it has been revealed that MLTs are getting more cut injuries during the handling of test tubes, cover slips and slides. 
About $7.7 \%$ of HCWs reported blood splashes to mucous membranes such as eyes or mouth. Attendants and labourers had least number of blood splashes while MLTs had highest number of exposures (15.4\%). Nearly $12 \%$ of doctors and nurses reported mucous membrane exposures. (Table 2)

Table 2: Occupational exposure to blood in healthcare setting

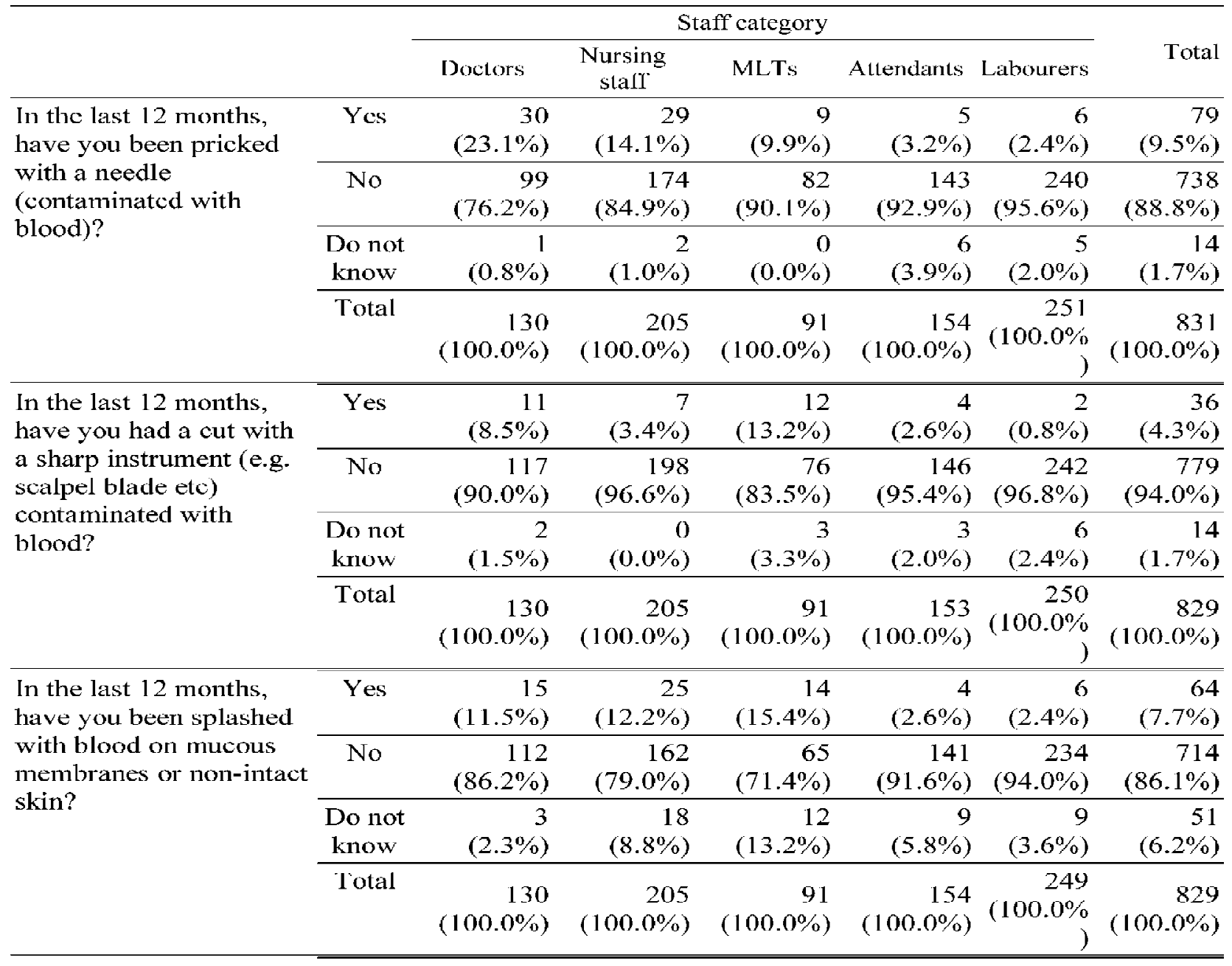

\section{(c). Knowledge of steps to be taken by healthcare worker on occupational exposures to blood}

The following table (Table 3) shows the preventive steps mentioned by HCWs when they are injured by a contaminated needle from a patient whose HIV status was unknown. Reporting to infection control staff and head of the unit had been mentioned by $83.3 \%$ and $63.7 \%$ of HCWs respectively. It was observed that the steps in managing occupational exposures were better known by nursing staff than doctors in the sample. MLTs, attendants and labours have decreasing knowledge in that order.
It is important to note that one third of HCWs (33\%) did not mention the step of washing with soap and water as a necessary precaution. No evidence exists that using antiseptics for wound care or expressing fluid by squeezing the wound further reduces the risk of transmission of blood borne pathogens; However, The use of antiseptics is not contraindicated (4). Squeezing to bleed has been mentioned by almost half $(46.5 \%)$ of the HCWs as a necessary step. Cleaning the wound with antiseptics was mentioned by $52 \%$ of HCWs 
Table 3: What steps would you take if you were to get stuck by a needle from a patient if you did not know whether or not the patient was HIV positive?

\begin{tabular}{lrrrrrr}
\hline & \multicolumn{5}{c}{ Staff category } & \\
\cline { 2 - 6 } & Doctors & $\begin{array}{r}\text { Nursing } \\
\text { staff }\end{array}$ & MLTs & Attendants Labourers & Total \\
\hline l.Wash with soap and water & 92 & 183 & 63 & 88 & 124 & 550 \\
& $70.8 \%$ & $89.3 \%$ & $69.2 \%$ & $57.1 \%$ & $49.4 \%$ & $66.2 \%$ \\
\hline 2.Clean wound with antiseptic & 77 & 115 & 56 & 63 & 123 & 434 \\
& $59.2 \%$ & $56.1 \%$ & $61.5 \%$ & $40.9 \%$ & $49.0 \%$ & $52.2 \%$ \\
\hline 3.Squeeze/bleed wound & 42 & 129 & 58 & 69 & 88 & 386 \\
& $32.3 \%$ & $62.9 \%$ & $63.7 \%$ & $44.8 \%$ & $35.1 \%$ & $46.5 \%$ \\
\hline 4.Dress the wound & 17 & 49 & 9 & 17 & 34 & 126 \\
& $13.1 \%$ & $23.9 \%$ & $9.9 \%$ & $11.0 \%$ & $13.5 \%$ & $15.2 \%$ \\
\hline 5.Report to Head & 68 & 162 & 61 & 92 & 146 & 529 \\
& $52.3 \%$ & $79.0 \%$ & $67.0 \%$ & $59.7 \%$ & $58.2 \%$ & $63.7 \%$ \\
\hline 6. Report to infection control & 104 & 189 & 75 & 125 & 199 & 692 \\
staff & $80.0 \%$ & $92.2 \%$ & $82.4 \%$ & $81.2 \%$ & $79.3 \%$ & $83.3 \%$ \\
Total subjects responded & 130 & 205 & 91 & 154 & 251 & 831 \\
\hline
\end{tabular}

These frequencies are not mutually exclusive

\section{(d). Knowledge on Post-Exposure Prophylaxis (PEP)}

Most HCWs believed that they should seek PEP when they get needle stick injuries from an HIV infected patient (82\%). This fact was better known by doctors (91\%), nurses (90\%) and MLTs (90\%) than attendants
(77\%) and labours (72\%). Nearly half of the HCWs did not know that they should seek HIV PEP when their mucous membranes or non-intact skin is exposed to blood irrespective of the HIV status of the source patient. About one third of HCWs believed that PEP for HIV was necessary whenever blood contacts with intact skin. (Table 4)

Table 4: Under what circumstances should a health care worker seek Post Exposure Prophylaxis (PEP) for HIV?

\begin{tabular}{lrrrrrr}
\hline & \multicolumn{5}{c}{ Staff category } & \\
\cline { 2 - 6 } & Doctors & $\begin{array}{r}\text { Nursing } \\
\text { staff }\end{array}$ & MLTs & Attendant & Total \\
& & & & & \\
\hline & 117 & 184 & 82 & 119 & 179 & 681 \\
\hline $\begin{array}{l}\text { 1.Needle stick injury from an HIV } \\
\text { patient }\end{array}$ & $90.7 \%$ & $89.8 \%$ & $90.1 \%$ & $77.3 \%$ & $71.6 \%$ & $82.1 \%$ \\
\hline 2.Any blood contact with mucous & 73 & 113 & 52 & 81 & 119 & 438 \\
membrane & $56.6 \%$ & $55.1 \%$ & $57.1 \%$ & $52.6 \%$ & $47.4 \%$ & $52.8 \%$ \\
\hline 3.Any blood contact with non-intact & 67 & 126 & 48 & 80 & 122 & 443 \\
skin & $51.9 \%$ & $61.5 \%$ & $52.7 \%$ & $51.9 \%$ & $48.6 \%$ & $53.4 \%$ \\
\hline 4.HIV positive blood contact with intact & 29 & 47 & 30 & 41 & 53 & 200 \\
skin & $22.5 \%$ & $22.9 \%$ & $33.0 \%$ & $26.6 \%$ & $21.1 \%$ & $24.1 \%$ \\
\hline
\end{tabular}

These frequencies are not mutually exclusive 


\section{(e). Prevention of occupational post exposure prophylaxis in healthcare settings.}

Opinions regarding the HIV prevention among healthcare workers showed different thoughts and expectations (Table 5). The majority of HCWs (77\%) believed that, they should take necessary precautions considering every patient could have HIV while $66 \%$ said that they need to wear special protection when touching HIV patients. HCWs also expect that they should be provided with enough gloves (55\%), clean running water to wash hands (46.8\%) and enough medicine for PEP (35.5\%).

About $97 \%$ of HCWs were willing to accept HIV patients to their hospitals whereas $26.6 \%$ thought HIV patients should be given a separate healthcare institution. About $32 \%$ of HCWs expected that patients HIV status should be disclosed to the staff. Nearly $20 \%$ wanted to test every patient for HIV.

Table 5: In your opinion, what should be done to prevent HIV transmission to workers of the hospital?

\begin{tabular}{|c|c|c|c|c|c|c|}
\hline & \multicolumn{5}{|c|}{ Staff category } & \multirow[b]{2}{*}{ Total } \\
\hline & Doctors & $\begin{array}{l}\text { Nursing } \\
\text { staff }\end{array}$ & MLTs & $\begin{array}{l}\text { Altendan } \\
\text { ts }\end{array}$ & $\begin{array}{l}\text { Labourer } \\
\text { s }\end{array}$ & \\
\hline 1.Supply enough gloves & $\begin{array}{r}95 \\
73.1 \% \\
\end{array}$ & $\begin{array}{r}136 \\
66.3 \% \\
\end{array}$ & $\begin{array}{r}71 \\
78.0 \% \\
\end{array}$ & $\begin{array}{r}66 \\
42.9 \% \\
\end{array}$ & $\begin{array}{r}88 \\
35.1 \% \\
\end{array}$ & $\begin{array}{r}456 \\
54.9 \% \\
\end{array}$ \\
\hline 2.Test every patients for HIV & $\begin{array}{r}10 \\
7.7 \%\end{array}$ & $\begin{array}{r}37 \\
18.0 \%\end{array}$ & $\begin{array}{r}22 \\
24.2 \%\end{array}$ & $\begin{array}{r}37 \\
24.0 \%\end{array}$ & $\begin{array}{r}52 \\
20.7 \%\end{array}$ & $\begin{array}{r}158 \\
19.0 \%\end{array}$ \\
\hline $\begin{array}{l}\text { 3. Wear special protection when } \\
\text { touching HIV patients }\end{array}$ & $\begin{array}{r}84 \\
64.6 \%\end{array}$ & $\begin{array}{r}146 \\
71.2 \%\end{array}$ & $\begin{array}{r}60 \\
65.9 \%\end{array}$ & $\begin{array}{r}114 \\
74.0 \%\end{array}$ & $\begin{array}{r}143 \\
57.0 \%\end{array}$ & $\begin{array}{r}547 \\
65.8 \%\end{array}$ \\
\hline $\begin{array}{l}\text { 4.Have enough clean running water to } \\
\text { wash hands }\end{array}$ & $\begin{array}{r}72 \\
55.4 \%\end{array}$ & $\begin{array}{r}128 \\
62.4 \%\end{array}$ & $\begin{array}{r}50 \\
54.9 \%\end{array}$ & $\begin{array}{r}62 \\
40.3 \%\end{array}$ & $\begin{array}{r}77 \\
30.7 \%\end{array}$ & $\begin{array}{r}389 \\
46.8 \%\end{array}$ \\
\hline $\begin{array}{l}\text { 5.Inform all hospital workers about } \\
\text { those patients who have HIV }\end{array}$ & $\begin{array}{r}28 \\
21.5 \%\end{array}$ & $\begin{array}{r}57 \\
27.8 \%\end{array}$ & $\begin{array}{r}29 \\
31.9 \%\end{array}$ & $\begin{array}{r}53 \\
34.4 \%\end{array}$ & $\begin{array}{r}101 \\
40.2 \%\end{array}$ & $\begin{array}{r}268 \\
32.3 \%\end{array}$ \\
\hline $\begin{array}{l}\text { 6.Supply enough post exposure } \\
\text { prophylaxis }\end{array}$ & $\begin{array}{r}84 \\
64.6 \%\end{array}$ & $\begin{array}{r}93 \\
45.4 \%\end{array}$ & $\begin{array}{r}49 \\
53.8 \%\end{array}$ & $\begin{array}{r}29 \\
18.8 \%\end{array}$ & $\begin{array}{r}40 \\
15.9 \%\end{array}$ & $\begin{array}{r}295 \\
35.5 \%\end{array}$ \\
\hline $\begin{array}{l}\text { 7.Do not accept HIV patients to } \\
\text { hospitals }\end{array}$ & $\begin{array}{r}6 \\
4.6 \%\end{array}$ & $\begin{array}{r}2 \\
1.0 \%\end{array}$ & $\begin{array}{r}4 \\
4.4 \%\end{array}$ & $\begin{array}{r}3 \\
1.9 \%\end{array}$ & $\begin{array}{r}6 \\
2.4 \%\end{array}$ & $\begin{array}{r}21 \\
2.5 \%\end{array}$ \\
\hline $\begin{array}{l}\text { 8.Assume that every patient has HIV } \\
\text { and always take Precautions }\end{array}$ & $\begin{array}{r}101 \\
77.7 \%\end{array}$ & $\begin{array}{r}197 \\
96.1 \%\end{array}$ & $\begin{array}{r}82 \\
90.1 \%\end{array}$ & $\begin{array}{r}98 \\
63.6 \%\end{array}$ & $\begin{array}{r}159 \\
63.3 \%\end{array}$ & $\begin{array}{r}637 \\
76.7 \%\end{array}$ \\
\hline $\begin{array}{l}\text { 9.HIV patients should have separate } \\
\text { healthcare institutions }\end{array}$ & $\begin{array}{r}34 \\
26.2 \%\end{array}$ & $\begin{array}{r}45 \\
22.0 \%\end{array}$ & $\begin{array}{r}37 \\
40.7 \%\end{array}$ & $\begin{array}{r}36 \\
23.4 \%\end{array}$ & $\begin{array}{r}69 \\
27.5 \%\end{array}$ & $\begin{array}{r}221 \\
26.6 \%\end{array}$ \\
\hline
\end{tabular}

These frequencies are not mutually exclusive

\section{Discussion}

Healthcare providers are not free of occupational risk when they deliver services for patients infected with blood borne infections including HIV. It is important to note that on the average $9.5 \%$ of HCWs had exposed to needle stick injuries whereas exposure to mucous membrane and cut injuries were $7.7 \%$ and $4.3 \%$ respectively. However, over $23 \%$ of doctors and $14 \%$ of nurses had needle pricks during the past year. This is a considerable number and ideally they all should be provided with HIV post-exposure counselling by a trained staff member. HIV PEP should also be available to be taken as early as possible when necessary.

Although the majority knows the fact that the injuries should be informed to the infection control unit or the 
head of the relevant units, significant number of HCWs (33\%) had not mentioned that the wound should be washed with soap and water. The knowledge on the immediate management of the wound is relatively known better by the nursing staff than doctors in the sample. Therefore, doctors should also be included in in-service training on infection control. It should also be emphasized that habit of squeezing has no any added benefit and theoretically it has negative effects as well, because the pressure on the site of injury can result in some epidermal scratches to bridge with the underlying dermal capillaries and also when the pressure is released at the injury site there is a negative pressure that can lead the fluid to go into the breached capillaries.

The general knowledge on post exposure prophylaxis is questionable and they seem to practice high riskhigh protection approach rather than standard precautions which should be used by all healthcare workers at all times when attending to all patients (5). Nearly half of the HCWs did not know that they should seek HIV PEP when their mucous membranes or non-intact skin is exposed to blood. About one third of HCWs believed that HIV PEP is needed for blood contacts with intact skin. In general, knowledge on PEP should be further updated and emphasised among HCWs.

The majority of HCWs seems to have realised that it is their responsibility to take necessary precautions considering the possibility that every patient could have HIV (77\%). However, their concerns of not having enough gloves clean running water and availability of PEP need attention. It is the responsibility of the hospital authorities to provide such basic requirements which are essential to protect healthcare workers at the work place. A high quality counselling service for PEP and regular in-service training on infection control are necessary steps to protect healthcare workers from getting possible blood borne infections and thereby protect the rights of patients.

\section{Limitations of the study}

There were several limitations at various levels of the study. The study population had to be confined to healthcare workers in six government institutions. The research team selected units known to have relatively more experience of care for HIV patients. Therefore, generalization of these results is limited to these selected hospitals and categories of staff.

The research team initially thought of getting a well representative probability sample of HCWs. However, the idea was abandoned due to the administrative difficulties which also limited the realistic generalization of the results.

In this study, recall period of one year, was added to some of the questions. Investigators had to decide this limit since the number of expected responses would have been low especially for needle stick injuries, and blood splashes if the recall period had been short. For better recall, the respondents were given enough privacy and time.

Possible bias was minimized in the data collection process. Self-administered questionnaire was developed with wide base consultation, FGDs and field testing was done to avoid ambiguity of questions. Special emphasis was given for the proper planning and wording of the Sinhalese and Tamil questionnaires

\section{References}

1. Report on HIV Estimation and Projections, Sri lanka. Colombo: National STD/AIDS Control Programme, Ministry of Health; 2009.

2. HIV/AIDS Surveillance Data in Sri Lanka. Colombo: National STD/AIDS Control Programme, Ministry of Health; 2011.

3. HIV Sentinel Sero-surveillance Survey in Sri Lanka. Colombo: National STD/AIDS Control Programme, Ministry of Health; September 2010.

4. Updated U.S. Public Health Service guidelines for the management of occupational exposures to $\mathrm{HBV}, \mathrm{HCV}$, and HIV and recommendations for postexposure prophylaxis., CDC; 2001.

5. Karunaratne K, Chinniah R, Chandrasiri P, Corea E, Elwitigala J, Navaratne V, editors. Hospital Infection Control Manual. First Edition ed. Colombo: Sri Lanka College of Microbiologists; 2005. 